\title{
CROSS-FLAMING APPLICATION FOR INTRA-ROW WEED CONTROL IN MAIZE
}

\author{
L. Martelloni, M. Fontanelli, C. Frasconi, M. Raffaelli, A. Peruzzi
}

\begin{abstract}
Flame weeding is the most common thermal intra-row weed control method used in agriculture as an alternative to herbicides in heat-tolerant crops. Within the seventh framework program project "Robot fleets for Highly Effective Agriculture and Forestry Management" (RHEA), the University of Pisa was responsible for the development of an automatic machine for intra-row cross-flaming in maize (Zea mays $L$.). This study focused on the selection of a range of liquid petroleum gas (LPG) doses able to control weeds without affecting crop yields, for the basic calibration of the machine. Tests were conducted in 2012 and 2013 during the growing cycle of maize both in weed-free and real-field weedy conditions. Five biological LPG doses $\left(0,52,65,104\right.$, and $\left.130 \mathrm{~kg} \mathrm{ha}^{-1}\right)$ were applied at different maize growth stages once (2-and 5-leaf) and twice (2-leaf the first time and 16 days after the first time). The response of maize and weeds to cross-flaming was evaluated in terms of grain yield, weed density after flame weeding, and weed dry biomass at harvest. Log-logistic models were used to describe the responses of different growth stages of maize and weeds to single and repeated applications of $L P G$ doses. Overall response of maize yield to flame weeding was influenced by LPG dose, number of flame weedings, maize growth stage, and presence of weeds. The results of this study indicate that two cross-flaming treatments applied separately with an LPG dose ranging from 36 to $42 \mathrm{~kg} \mathrm{ha}^{-1}$ can provide an acceptable level of weed control in maize, enough to ensure economically acceptable yields.
\end{abstract}

Keywords. Cross flaming maize, Dose-response curves, Flame engineering technology, Flame weeding machine, Integrated weed management, Intra-row weed control, Nonchemical weed control, Organic farming.

W eeds are responsible for significant crop yield reductions (Peruzzi et al., 2007; Datta and Knezevic, 2013; Fontanelli et al., 2013). Flaming is the most common thermal weed control method used in agriculture in both organic and conventional systems (Ascard, 1995), as an alternative to herbicide applications (Peruzzi et al., 2007; Datta and Knezevic, 2013; Fontanelli et al., 2013). Liquid petroleum gas (LPG) is commonly used to feed burners and generate flames at an average temperature of about $1500^{\circ} \mathrm{C}$. This heats the exposed leaves very rapidly, thus devitalizing the weeds without burning them (Ascard, 1995). Heat exposure denaturizes plant proteins, which results in the loss of cell function, causes intracellular water expansion, ruptures cell membranes, and finally desiccates the weeds, normally within

Submitted for review in December 2014 as manuscript number MS 11114; approved for publication by the Machinery Systems Community of ASABE in February 2016.

The authors are Luisa Martelloni, Postdoctoral Fellow, Centro di Ricerche Agro-Ambientali "Enrico Avanzi," University of Pisa, San Piero a Grado Pisa, Italy; Marco Fontanelli, Researcher, Christian Frasconi, Researcher, Michele Raffaelli, Associate Professor, and Andrea Peruzzi, Full Professor, Department of Agriculture, Food and Environment, University of Pisa, Pisa, Italy. Corresponding authors: Luisa Martelloni, Centro di Ricerche Agro-Ambientali "Enrico Avanzi," University of Pisa, Via Vecchia di Marina 6, 56122, San Piero a Grado, Pisa, Italy; phone: 0039-050-2218966; e-mail: lmartelloni@agr.unipi.it; and Marco Fontanelli, Department of Agriculture, Food and Environment, University of Pisa, Pisa, Italy; phone: 0039-050-2218922; e-mail: marco.fontanelli@unipi.it. two to three days (Mojžiš, 2002). There are three fundamental types of burners available at the market: open flame with cover $\left(\mathrm{T} \max =1900^{\circ} \mathrm{C}\right)$, open flame without cover $\left(\mathrm{T} \max =1500^{\circ} \mathrm{C}\right.$ ), and infrared $\left(\mathrm{T} \max =500^{\circ} \mathrm{C}\right.$ ) (Ascard, 1995; Rask et al., 2012; Knezevic et al., 2013; Raffaelli et al., 2013).

The main advantages of flame weeding include the lack of chemical residues in the crop, soil, and water; the lack of herbicide carryover to the next season; the very wide spectrum of weeds controlled; and the lack of resistance to flaming (Ascard, 1995; Mojžišs, 2002; Fontanelli et al., 2013). Flame weeding can be used in pre-sowing, pre-emergence or pre-transplanting in order to devitalize the weeds that emerge prior to the crop (Hatcher and Melander, 2003; Peruzzi et al., 2007). Post-emergence flame weeding lends itself in heat-tolerant crops such as maize (Zea mays L.), soybean (Glycine max L.), sorghum (Sorghum vulgare Pers.) (Ulloa et al., 2011a,b; Knezevic et al., 2013), and onion (Allium cepa L.) (Sivesind et al., 2012).

Ulloa et al. (2011a) tested the response of maize to broadcast flaming. The 5-leaf growth stage was the most tolerant to broadcast flaming, whereas the 2-leaf growth stage was the most susceptible, resulting in the highest visual crop injury ratings, dry matter reduction, and the largest loss of yield. Knezevic et al. (2013) applied a propane dose of $50 \mathrm{~kg} \mathrm{ha}^{-1}$ parallel to the soybean rows at an operating speed of $4.8 \mathrm{~km} \mathrm{~h}^{-1}$. They found that soybean can tolerate a maximum of two flaming treatments at unfolded cotyledonary and fifth trifoliate growth stages per season without any re- 
duction in yield. Ulloa et al. (2011b) investigated the response of sorghum to broadcast flaming as influenced by propane dose and crop growth stage. The results highlighted that the maximum yield reductions caused by the use of the highest propane dose of $85 \mathrm{~kg} \mathrm{ha}^{-1}$ were $11 \%, 6 \%$, and $9 \%$ for 3-leaf, 5-leaf, and 7-leaf growth stages, respectively.

Many interesting studies have been conducted to test the effectiveness of flame weeding in controlling weeds, revealing that the growth stage at the time of flaming determines the weed sensitivity to heat. Flame weeding is more effective on weeds at early growth stages (Ascard 1994, 1995; Cisneros and Zandstra 2008; Knezevic et al., 2014; Mojžiš, 2002; Sivesind et al., 2009; Ulloa et al., 2010b, c). However, no experiments have been conducted in a real-field cultivation of maize, where crop and weeds were growing simultaneously, in order to select a range of flame weeding doses for economically acceptable weed control and crop yields.

The aim of this research was to select a range of LPG doses able to prevent crop yield losses, due to both weed competition and the crop's low tolerance to high doses, for the basic calibration of an automatic flame weeding machine designed and built within the RHEA Project (RHEA Project, 2014) by the University of Pisa (Frasconi et al., 2014). Tests were conducted during the growing cycle of maize both in weed-free, to eliminate the competitive effects of weeds, and in real-field weedy conditions, in order to study the effect of LPG doses on crop and weeds simultaneously.

\section{MATERIALS AND METHODS \\ MACHINE SET UP}

Within the RHEA project (RHEA Project, 2014), the University of Pisa was responsible for developing an automatic flame-weeding machine able to perform a variable rate application (VRA) for intra-row weed control (Frasconi et al., 2014). The machine uses LPG for combustion. Tests were performed in order to select a range of LPG doses that control weeds without affecting crop yields. Investigations were conducted in terms of the basic calibration of the machine and its application for maize. The open-flame burners of the machine $(0.25 \mathrm{~m}$ wide) produced a flat flame and were regulated in order to perform cross-flaming. Burners were angled at $45^{\circ}$ from the perpendicular to the ground and at $30^{\circ}$ from the parallel to the crop row. They were positioned at about $5 \mathrm{~cm}$ from each side of the crop row and $12 \mathrm{~cm}$ above the soil surface. Cross-flaming was applied by pairs of burners in $0.25 \mathrm{~m}$ wide soil strips (the intra-row space) with maize plants placed in the middle (fig. 1). Five LPG doses $\left(0,52,65,104\right.$ and $130 \mathrm{~kg} \mathrm{ha}^{-1}$ of flamed surface) were applied combining two working pressures $(0.3$ and $0.4 \mathrm{MPa})$ with two working speeds $\left(3\right.$ and $\left.6 \mathrm{~km} \mathrm{~h}^{-1}\right)$. The LPG doses were calculated as intra-row biological doses. The actual doses, computed on the full width of the machine, were lower than the biological doses $\left(0,17,22,35\right.$, and $43 \mathrm{~kg} \mathrm{ha}^{-1}$ of flamed plus unflamed surface, respectively).

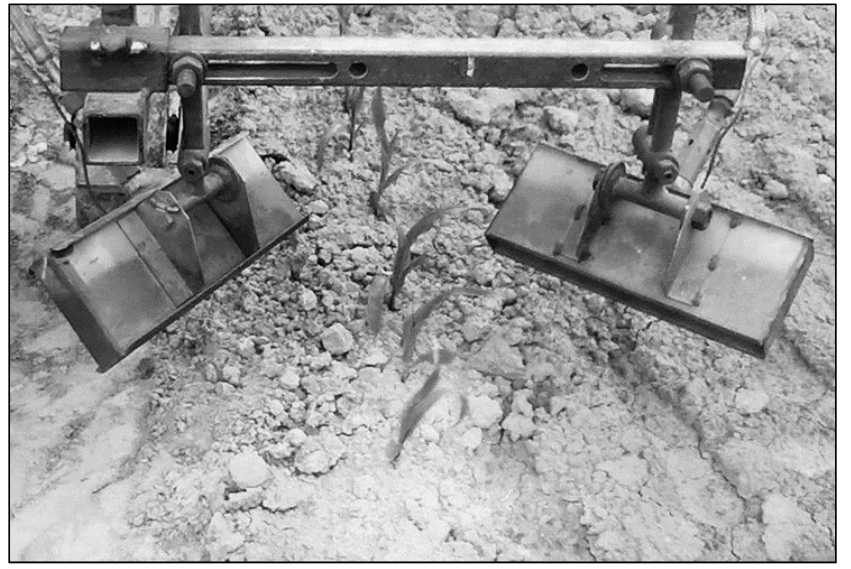

Figure 1. Cross-flaming treatment applied at 2-leaf growth stage of maize.

\section{EXPERIMENT SET UP}

Field experiments were conducted in the 2012 and 2013 maize growing seasons at the experimental farm of the University of Pisa $\left(+43.7^{\circ} \mathrm{N}+10.3^{\circ} \mathrm{E}\right)$ located in San Piero a Grado, close to Pisa, in central Italy. In both years the trial was conducted on the same site of 5 ha. The soil type was loam $(52 \%$ sand, $38 \%$ silt, $17 \%$ clay, $1.8 \%$ organic matter, $\mathrm{pH}$ of 8.2 , and CEC of 11). The previous crop was maize. Soil tillage included a shallow ploughing $(0.25 \mathrm{~m}$ deep $)$ and two passes of a rotary harrow. Fertilization consisted in the application of N-P-K at 32-96-96 $\mathrm{kg} \mathrm{ha}^{-1}$ and $92 \mathrm{~kg} \mathrm{~N} \mathrm{ha}^{-1}$ (urea) before the second hoeing and $92 \mathrm{~kg} \mathrm{~N} \mathrm{ha}^{-1}$ (urea) postemergence. FAO 500 maize hybrid was used. Sowing was conducted on 3 May 2012 and on 8 May 2013 using a fourrow planter with an inter-row distance of $0.75 \mathrm{~m}$ at a density of 83000 seeds ha $^{-1}$. Cultivation was performed after each flame weeding application in order to control weeds in the inter-row space. Maize was harvested on 17 September 2012 and on 23 September 2013. The trends in total monthly rainfall, irrigation (by sprinkling) and temperatures (min and max) recorded during the growing seasons in 2012 and 2013 are shown in table 1 .

\section{EXPERIMENTAL DESIGN AND TREATMENTS}

The experimental plot size was $15 \times 3 \mathrm{~m}$. From the $15 \times$ $3 \mathrm{~m}$ area, a $5 \times 3 \mathrm{~m}$ area was kept weed-free during the entire growing season by manual hoeing as weeds appeared, and the remaining $10 \times 3 \mathrm{~m}$ area was maintained under a realfield weedy condition. The treatments were arranged in a randomized complete block design with three replications. Cross-flaming was applied at different maize growth stages with five different biological LPG doses $(0,52,65,104$, and $\left.130 \mathrm{~kg} \mathrm{ha}^{-1}\right)$. Maize growth stage was assessed according to the leaf collar method (Nielsen, 2010). Maize growth stages were V2 (when the collar of the second leaf is visible), V5 (when the collar of the fifth leaf is visible), and DOUBLE (maize flamed once at V2 and the second time when the nonflamed weed-free control was at V5) (table 2). When the nonflamed weed-free control was at V5, maize already flamed at V2 was at V3 or V4, as a consequence of the effect 
Table 1. Total monthly rainfall, irrigation and temperatures recorded at San Piero a Grado (Pisa) during the 2012 and 2013 maize growing seasons (Consorzio LaAMMA, 2013).

\begin{tabular}{|c|c|c|c|c|c|c|c|c|}
\hline \multirow[b]{3}{*}{ Crop Month } & \multicolumn{4}{|c|}{2012} & \multicolumn{4}{|c|}{2013} \\
\hline & \multicolumn{2}{|c|}{ Temperature $\left({ }^{\circ} \mathrm{C}\right)$} & \multirow{2}{*}{$\begin{array}{l}\text { Precipitation } \\
\text { (mm) }\end{array}$} & \multirow{2}{*}{$\begin{array}{c}\text { Irrigation } \\
(\mathrm{mm})\end{array}$} & \multicolumn{2}{|c|}{ Temperature $\left({ }^{\circ} \mathrm{C}\right)$} & \multirow{2}{*}{$\begin{array}{c}\text { Precipitation } \\
(\mathrm{mm})\end{array}$} & \multirow{2}{*}{$\begin{array}{c}\text { Irrigation } \\
(\mathrm{mm})\end{array}$} \\
\hline & Minimum & Maximum & & & Minimum & Maximum & & \\
\hline May & 16.4 & 21.9 & 56 & 0 & 11.8 & 19.6 & 62 & 0 \\
\hline June & 21.5 & 27.3 & 4 & 0 & 13.9 & 24.6 & 18 & 0 \\
\hline July & 24.1 & 29.5 & 0 & 50 & 18.7 & 29.7 & 4 & 50 \\
\hline August & 25.1 & 30.7 & 11 & 70 & 18.6 & 30.1 & 7 & 70 \\
\hline September & 20.6 & 27.1 & 75 & 0 & 16.0 & 26.0 & 91 & 0 \\
\hline
\end{tabular}

of the different LPG doses applied at V2 (table 2). The treatments consisted of one nonflamed weed-free control, one nonflamed weedy control, and four LPG doses, which were applied at different maize growth stages (V2, V5, and DOUBLE), resulting in a total of 14 treatments both in weed-free and real-field weedy conditions. Cross-flaming was applied at V2 and V5 with LPG doses of 52, 65, 104, and $130 \mathrm{~kg} \mathrm{ha}$ ${ }^{1}$, and at DOUBLE with the same LPG doses but applied the first time when maize was at V2 and the second time after 16 days from the first application, that is when the nonflamed weed-free control was at V5 and the maize treated previously was at V3 or V4 depending on the dose applied the first time (table 2). Flame weeding was applied on 23 May and 8 June, which corresponded to the growth stages of V2 and V5, respectively, in 2012. In 2013 maize was flamed on 28 May and 13 June, which corresponded to the same growth stages flamed in 2012 (table 2). The initial composition of weed flora in 2 years comprised $64 \%$ Chenopodium album L., 20\% Datura stramonium L. and 16\% other species (Solanum nigrum L., Amaranthus retroflexus L., Cynodon dactylon L.).

\section{Data Collection}

Maize yield was determined by collecting samples from a $3 \mathrm{~m}^{2}$ area $(4 \times 0.75 \mathrm{~m})$ placed in the middle two rows of each plot in both weed-free and real-field weedy conditions. Cobs were shelled, and the kernel was dried at $105^{\circ} \mathrm{C}$ to constant weight. Weed density data were collected 7, 14, and 21 days after flame weeding at V2, and 7 days after flame weeding at V5. When maize was flamed at the DOUBLE stage, weed density was collected 7 days after first flame weeding, 1 day before the second flame weeding and 7 days after the second flame weeding. All weed density samples were collected from a $0.075 \mathrm{~m}^{2}(0.25 \times 0.30 \mathrm{~m})$ area in three randomly selected sampling points within the real-field weedy plots. Weed dry biomass at harvest was measured after collecting weeds from a $1.5 \mathrm{~m}^{2}(0.25 \mathrm{~m} \times 3 \mathrm{~m} \times 2)$ area placed in the middle two intra-rows of each weedy plot. Weeds were cut without roots and dried at $105^{\circ} \mathrm{C}$ to constant weight.

\section{Statistical AnAlysis}

Initial testing of the effect of years, treatments, replications, and their interactions on the basis of maize yield, weed density, and weed dry biomass at harvest were analyzed for significance using a linear mixed model ANOVA. The R statistical software (R Core Team, 2013) with the extension package lmerTest (Kuznetsova et al., 2014) was used to analyze the linear mixed model of maize yield (in weed free and real-field weedy conditions) and weed dry biomass at harvest. The extension package lme4 (Bates et al., 2014) was used to analyze the generalized linear mixed model of weed density (the family Poisson and link=log was assessed). Nonsignificant fixed effects and interactions were excluded from the model. There was no treatment-by-year interaction, thus the data were combined over years. A significant effect of maize growth stage on the flame weeding treatment was observed; therefore, the data were presented separately for each growth stage.

The responses of maize and weeds to cross-flaming were analyzed using nonlinear regression analysis of dose-response curves. The extension package $d r c$ (dose-response curves) (Ritz and Streibig, 2005) of R (R Core Team, 2013) was chosen to fit nonlinear regressions, estimate their parameter values, effective doses, relative potency, predicted values, and plot the distribution of data and regression lines.

Yield (with the exception of yield when maize was flamed at the DOUBLE stage in weedy conditions), weed dry biomass, and weed density data were analyzed using the four parameter log-logistic model (Seefeldt et al., 1995; Knezevic et al., 2007) (eq. 1):

$$
Y=C+\frac{(D-C)}{\{1+\exp [B(\log X-\log E)]\}}
$$

where $Y$ is the response, $C$ is the lower limit, $D$ is the upper limit, $B$ is the slope of the line at the inflection point, $X$ is the LPG dose, and $E$ is the dose giving a $50 \%$ response between the upper and the lower limit (also known as the inflection point or $\mathrm{ED}_{50}$ ) (Seefeldt et al., 1995). For weed density model type $=$ Poisson was set. A test of lack-of-fit at the $95 \%$

Table 2. Maize growth stage, number of cross-flaming applications, dates of application, and leaves with visible collar at the time of flame weeding each year both in weed-free and real-field weedy conditions.

\begin{tabular}{ccccc}
\hline & No. of & \multicolumn{2}{c}{ Date of Application } & No. of Leaves with \\
\cline { 2 - 4 } Maize Growth Stage & Applications & 2012 & 2013 & Visible Collar \\
\hline V2 $^{[\mathrm{a}]}$ & 1 & 23 May & 28 May & 2 \\
V5 $^{[\mathrm{b}]}$ & 1 & 8 June & 13 June & 5 \\
DOUBLE $^{[\mathrm{c}]}$ & 2 & 23 May and 8 June & 28 May and 13 June & 2(first time) and 3 or 4 (second time) \\
\hline
\end{tabular}

${ }^{[a]} \mathrm{V} 2=2$-leaf stage

${ }^{[b]} \mathrm{V} 5=5$-leaf stage

${ }^{[c]}$ DOUBLE $=$ 2-leaf plus 3 or 4-leaf stage. 
level was not significant for any of the dose-response curves tested, which means that the non-linear regression model provides an acceptable description of the data (Ritz and Streibig, 2005).

Yield data when maize was flamed at the DOUBLE stage in weedy conditions showed a peak at low doses, after the peak yield decreased by increasing the LPG dose. In order to estimate the LPG dose for maximum yield, yield data were analyzed using the Cedergreen-Ritz-Streibig modified loglogistic model for describing hormesis (Cedergreen et al., 2005) (eq. 2):

$$
Y=C+\frac{D-C+F \exp \left(-1 /\left(X^{\alpha}\right)\right)}{1+\exp (B(\log X-\log E))}
$$

where $Y$ is the response, $D$ denotes the untreated control, $C$ is the response at infinite dose application, $F$ is the size of the hormesis effect, $X$ is the LPG dose, $B$ and $E$ have no direct interpretation. $F=0$ corresponds to no hormesis effect, and the resulting model is the four-parameter log-logistic model. The value $\alpha$ governs the rate at which the hormetic effect manifests itself (Cedergreen et al., 2005). The size of $\alpha$ was fixed at the level 0.5 . F parameter was $>0$ ( $p$ value $=0.00$ ) indicating the presence of hormesis.

Predicted response values for models were calculated by using the "predict.drc" function in $d r c$ (Ritz and Streibig, 2005). The ED-levels at the LPG dose producing $2.5 \%, 5 \%$, and $10 \%$ yield losses and $70 \%, 80 \%$, and $90 \%$ weed control were calculated from fitted dose-response curves (Ritz et al., 2006). The relative potency among relative response levels of curves was calculated using the "SI" ratio test function in $d r c$ (Ritz and Streibig, 2005). If the corresponding p-value was < 0.05 , the null hypothesis that compared doses were equal was rejected (Ritz and Streibig, 2012).

Relative potency from independent models was calculated using the "comped" function in $d r c$ (Ritz and Streibig, 2005), choosing "" for the argument "operator" and "FALSE" for the argument "log." If the resulting 95\% confidence interval (CI) for the ratio not crosses the value 1, the null hypothesis that compared doses was equal was rejected (Ritz and Streibig, 2012). The same ratio test was used to detect differences between the regression parameters and predicted response values of interest (Wheeler et al., 2005). The decision to use a ratio test instead of a CI overlap test was due to the conservative nature of the CI overlap test which would have reduced the ability of the test to detect differences when, in fact, they did occur. The power of the ratio test is greater than that of the CI overlap test (Wheeler et al., 2005).

\section{RESULTS}

\section{TEST IN WEED-FreE CONDITIONS}

The maize yield generally decreased with an increase in the LPG dose at each maize growth stage (fig. 2). Yields of nonflamed weed-free control were $18.2 \mathrm{Mg} \mathrm{ha}^{-1}$ (upper limit of the curve) (fig. 2, table 3). Yields in plots flamed with the highest LPG dose (e.g. $130 \mathrm{~kg} \mathrm{ha}^{-1}$ at V2 and V5, and $130 \mathrm{~kg}$

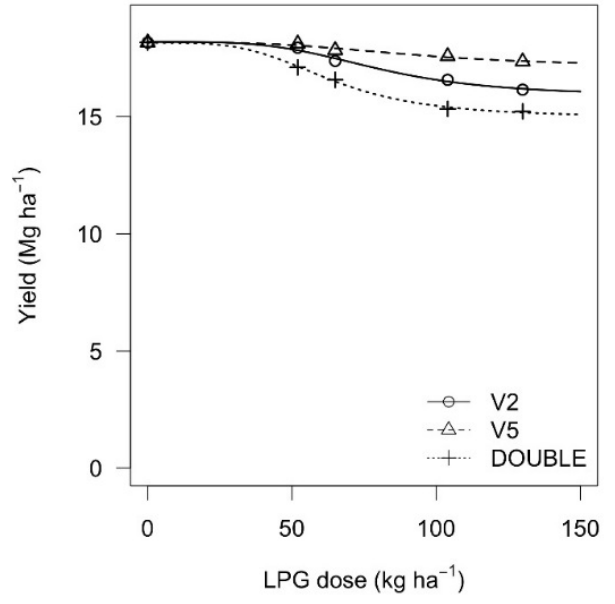

Figure 2. Influence of cross-flaming on maize yield $\left(\mathrm{Mg} \mathrm{ha}^{-1}\right)$ as affected by LPG dose and maize growth stage (V2: 2-leaf; V5: 5-leaf; DOUBLE: 2-leaf plus 3 or 4-leaf) under weed-free conditions. DOUBLE was flamed twice at an interval of $\mathbf{1 6}$ days. The regression lines are plotted using equation 1, and the parameters are presented in table 3.

ha $^{-1}$ applied twice at an interval of 16 days in DOUBLE) were $15.9,17.1$, and $15.0 \mathrm{Mg} \mathrm{ha}^{-1}$ (lower limit of the curve), respectively (fig. 2, table 3 ). When maize was flamed with the highest LPG dose, V5 yield was larger compared with the V2 and DOUBLE yields, respectively. The V2 yield was larger compared with the DOUBLE yield. These results suggest that V5 might be the most tolerant stage to flame weeding and DOUBLE might be the least tolerant stage.

Table 3 reports the estimated LPG doses at ED-levels needed to obtain $2.5 \%, 5 \%$ and $10 \%$ yield losses. With a minimum yield of $17.1 \mathrm{Mg} \mathrm{ha}^{-1}$ observed at the V5 stage (table 3), it was not possible to calculate the LPG dose needed to cause a $10 \%$ yield loss. Estimated relative potencies show that LPG doses from the V5 and V2 curves that were required to obtain a yield loss of $2.5 \%$ and $5 \%$ were statistically equal to 1 (table 4). These results were due to the high standard errors observed for the estimated LPG doses at V5 and should not be biologically significant. If maize is flamed at V5 with an LPG dose $>66.1 \mathrm{~kg} \mathrm{ha}^{-1}$ and $<77.7 \mathrm{~kg} \mathrm{ha}^{-1}$ and $>52.8 \mathrm{~kg} \mathrm{ha}^{-1}$ and $<58.7 \mathrm{~kg} \mathrm{ha}^{-1}$, the same range of LPG doses might be applied at V2 and cause the same yield loss of 5\% and $2.5 \%$, respectively. By applying an LPG dose $>77.7 \mathrm{~kg} \mathrm{ha}^{-1}$ and $>58.7 \mathrm{~kg}$ ha $^{-1}$ at V2, the yield loss might be higher than $5 \%$ and $2.5 \%$, respectively.

In order to produce the same $10 \%, 5 \%$ and $2.5 \%$ yield losses, when maize was flamed twice during the growing season at the DOUBLE stage, the LPG dose needed each time (16-day interval) was smaller compared with that applied only once at V2 or V5 (table 4).

\section{TEST IN REAL-FIELd WEEdy CONDITIONS Weed Density}

Weed composition before flame weeding was mixed, due to the test conducted in real-field conditions, and comprised $64 \%$ Chenopodium album L., 20\% Datura stramonium L. and $16 \%$ other species (Solanum nigrum L., Amaranthus retroflexus L., Cynodon dactylon L.). Weed density was affected by the LPG dose at the three maize growth stages (fig. 3). Weeds at the time of flame weeding applied at V2 growth 
Table 3. Regression parameters for maize yield $\left(\mathrm{Mg} \mathrm{ha}^{-1}\right)$ as affected by LPG dose, and LPG doses (kg ha $\left.^{-1}\right) \mathrm{needed}$ to cause losses of $2.5 \%, 5 \%$ and $10 \%$ in maize yield at three maize growth stages under weed-free conditions.

\begin{tabular}{|c|c|c|c|c|c|c|c|}
\hline \multicolumn{8}{|c|}{ Yield $\left(\mathrm{Mg} \mathrm{ha}^{-1}\right)$} \\
\hline \multirow[b]{2}{*}{ Growth Stage } & \multicolumn{4}{|c|}{ Regression Parameters $( \pm \mathrm{SE})$} & \multicolumn{3}{|c|}{ LPG Dose $( \pm \mathrm{SE})$} \\
\hline & $\mathrm{B}^{[\mathrm{a}]}$ & $\mathrm{C}^{[\mathrm{b}]}$ & $\mathrm{D}^{[\mathrm{c}]}$ & $\mathrm{E}^{[\mathrm{d}]}$ & $2.5 \%$ loss & $5 \%$ loss & $10 \%$ loss \\
\hline $\mathrm{V} 2^{[\mathrm{e}]}$ & $3.9(0.39)$ & $15.9(0.14)$ & $18.2(0.03)$ & $80.3(3.97)$ & $55.8(1.49)$ & $71.9(2.90)$ & $112.5(9.05)$ \\
\hline $\mathrm{V} 5^{[\mathrm{f}]}$ & $3.3(0.84)$ & $17.1(0.27)$ & $18.2(0.03)$ & $91.7(18.33)$ & $83.2(14.79)$ & $155.8(51.05)$ & - \\
\hline DOUBLE $^{[\mathrm{g}]}$ & $3.8(0.27)$ & $15.0(0.07)$ & $18.2(0.03)$ & $63.7(1.17)$ & $39.5(1.01)$ & $50.0(0.73)$ & $68.6(1.53)$ \\
\hline
\end{tabular}

[a] $\mathrm{B}=$ slope of the curve at the inflection point.

[b] $\mathrm{C}=$ lower limit. The value of $\mathrm{C}$ is the yield when the highest LPG dose was applied.

[c] $\mathrm{D}=$ upper limit. The value of $\mathrm{D}$ is the yield of the nonflamed weed-free control.

[d] $\mathrm{E}=$ dose of LPG resulting in a 50\% response between the upper and the lower limit.

[e] $\mathrm{V} 2=2$-leaf stage.

[f] $\mathrm{V} 5=5$-leaf stage.

[g] DOUBLE $=$ 2-leaf plus 3 or 4-leaf stage.

Table 4. Comparison of potencies among relative response levels (producing $2.5 \%, 5$ and $10 \%$ yield losses) from curves V2 (2-leaf), V5 (5-leaf), and DOUBLE (2-leaf plus 3- or 4-leaf) presented in figure 2.

\begin{tabular}{lcc}
\hline Response Level & $\begin{array}{c}\text { Relative Potency } \\
( \pm \text { SE })\end{array}$ & p-value $^{[\mathrm{a}]}$ \\
\hline 10\% loss & $1.64(0.14)$ & 0.00 \\
$\quad$ V2/DOUBLE:79/57 & $2.17(0.72)$ & 0.11 \\
5\% loss & $1.44(0.06)$ & 0.00 \\
$\quad$ V5/V2:85/39 & $3.18(1.06)$ & 0.04 \\
V2/DOUBLE:39/29 & & \\
V5/DOUBLE:86/29 & $1.49(0.27)$ & 0.07 \\
2.5\% loss & $1.41(0.05)$ & 0.00 \\
V5/V2:42/20 & $2.11(0.38)$ & 0.00 \\
V2/DOUBLE:20/14 & & \\
V5/DOUBLE:43/14 & & \\
\hline p-value $<0.05$ means that the estimated ratio value is different from 1.
\end{tabular}

stage of maize were at the cotyledonary stage. Seven days after treatment (DAT), weed density in the nonflamed weedy control was 111-fold larger compared with weed density in plots flamed with the highest LPG dose (table 5). Predicted weed density in plots flamed with the LPG dose of $52 \mathrm{~kg} \mathrm{ha}^{-1}$ (the second lower LPG dose tested) was $7.8( \pm 0.61)$ plants $\mathrm{m}^{-2}$, 4-fold larger compared with weed density measured in plots flamed with the highest LPG dose.

In plots flamed at V2, weed density after flame weeding increased over time (fig. 3). Weed density 14 DAT and 21 DAT was larger than 7 DAT (table 5). When maize was flamed with 52 and $130 \mathrm{~kg} \mathrm{ha}^{-1}$, comparisons between estimated indices increased from 7 to $14 \mathrm{DAT}$, and from 7 to 21 DAT, respectively, were statistically not different from 1 (95\% CIs $0.47,3.09$ and $0.53,3.42$, respectively), meaning that these increases did not depend on the LPG dose and were the result of new weeds emerging after flame weeding. Due to these newly emerged weeds, at 21 DAT the weed density increased from 2-fold to 12-fold compared with weed density observed at 7 DAT.

A similar weed increase compared with that observed at 7 DAT when maize was flamed at V2, was observed one day before the second flaming (1 DBST) at the DOUBLE growth stage (fig. 3). Seven days after the second treatment (7 DAST) there was a 12 -fold weed density decease i.e. similar to the weed density for 7 DAFT (fig. 3, table 5). This means that by applying flame weeding twice (16-day interval), it is possible to extend the time of maize's competitive advantage compared with only one application at V2 (fig. 3).

When flame weeding was applied at V5, weeds were at a mixed growth stage, due to the scalar weed emergence. The maximum weed growth stage observed in V5 plots was 11leaf (comprised mainly Chenopodium album L.). Weed density decreased as the LPG dose increased (fig. 3) but was always larger compared with that observed in V2 plots. This suggests that flame weeding might be effective only on small weeds. When maize was flamed at V5 with the highest LPG
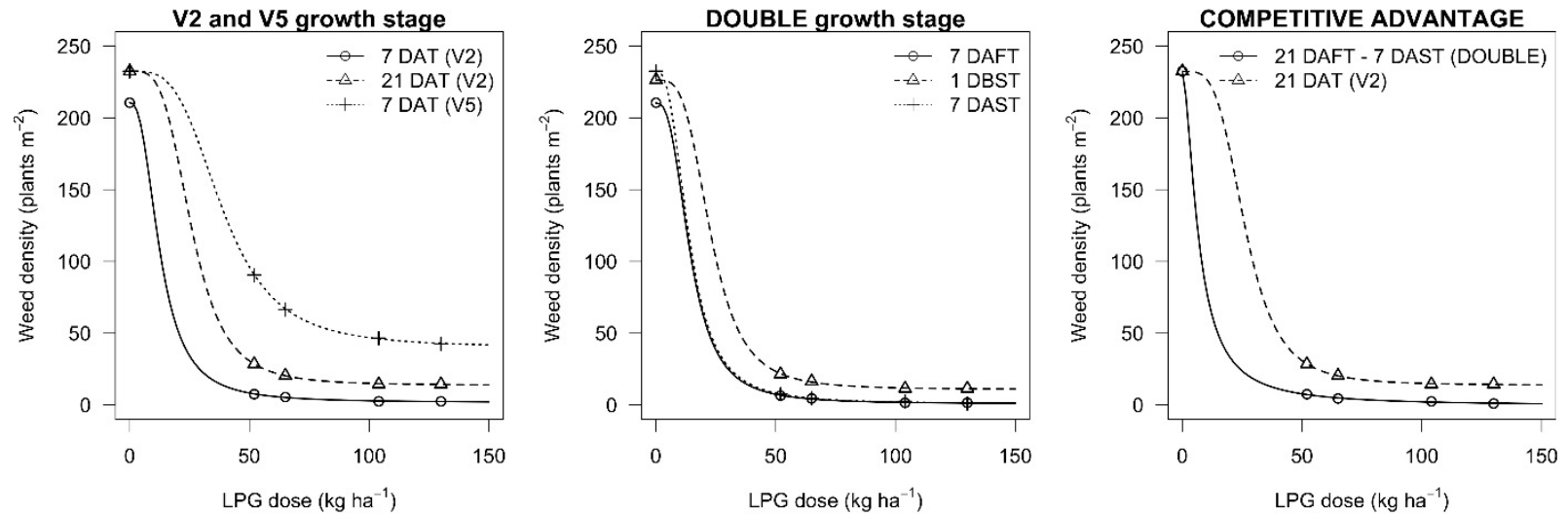

Figure 3. Influence of cross-flaming on weed density (plants $\mathrm{m}^{-2}$ ) as affected by LPG dose and time of treatment (corresponding to maize growth stage) at different times before or after flame weeding (V2: 2-leaf; V5: 5-leaf; DOUBLE: 2-leaf plus 3- or 4-leaf; DAT: days after treatment; DAFT: days after first treatment; DBST: days before second treatment; DAST: days after second treatment) under real-field weedy conditions. DOUBLE was flamed twice at an interval of 16 days. The regression lines are plotted using equation $\mathbf{1}$, and the parameters are presented in table 5. 
Table 5. Regression parameters for weed density as affected by LPG dose and time of treatment (corresponding to maize growth stage) at different times before or after flame weeding under real-field weedy conditions.

\begin{tabular}{|c|c|c|c|c|c|}
\hline \multicolumn{6}{|c|}{ Weed Density (plants $\mathrm{m}^{-2}$ ) } \\
\hline \multirow[b]{2}{*}{ Growth Stage } & \multirow[b]{2}{*}{ Time of Flame-Weeding } & \multicolumn{4}{|c|}{ Regression Parameters $( \pm \mathrm{SE})$} \\
\hline & & $\mathrm{B}^{[\mathrm{a}]}$ & $\mathrm{C}^{[\mathrm{b}]}$ & $\mathrm{D}^{[\mathrm{c}]}$ & $\mathrm{E}^{[\mathrm{d}]}$ \\
\hline $\mathrm{V} 2^{[\mathrm{e}]}$ & $7 \mathrm{DAT}^{[\mathrm{f}]}$ & $2.8(1.06)$ & $1.9(0.67)$ & $210.6(3.42)$ & $14.8(6.71)$ \\
\hline $\mathrm{V} 2^{[\mathrm{e}]}$ & $14 \mathrm{DAT}^{[\mathrm{f}]}$ & $3.9(1.05)$ & $9.9(0.86)$ & $226.5(3.55)$ & $25.4(4.87)$ \\
\hline $\mathrm{V} 2^{[\mathrm{e}]}$ & $21 \mathrm{DAT}^{[\mathrm{f}]}$ & $3.9(1.18)$ & $13.8(1.07)$ & $232.3(3.59)$ & $26.7(5.24)$ \\
\hline $\mathrm{V}^{[\mathrm{g}]}$ & $7 \mathrm{DAT}^{[\mathrm{f}]}$ & $3.6(0.63)$ & $40.4(2.52)$ & $232.4(3.59)$ & $38.7(2.07)$ \\
\hline DOUBLE $^{[\mathrm{h}]}$ & $7 \mathrm{DAFT}^{[\mathrm{i}]}$ & $2.7(1.17)$ & $0.9(0.40)$ & $210.2(3.42)$ & $14.3(7.61)$ \\
\hline DOUBLE $^{[\mathrm{h}]}$ & $1 \mathrm{DBST}^{[\mathrm{j}]}$ & $3.6(1.41)$ & $10.8(1.14)$ & $226.3(3.54)$ & $22.9(7.17)$ \\
\hline DOUBLE $^{[\mathrm{h}]}$ & $7 \mathrm{DAST}^{[\mathrm{k}]}$ & $2.7(0.83)$ & $0.9(0.41)$ & $232.5(3.60)$ & $13.8(5.5)$ \\
\hline
\end{tabular}

[a] $\mathrm{B}=$ slope of the curve at the inflection point.

[b] $\mathrm{C}=$ lower limit. The value of $\mathrm{C}$ is the weed density when the highest LPG dose was applied.

[c] $\mathrm{D}=$ upper limit. The value of $\mathrm{D}$ is the weed density of the nonflamed weedy control.

[d] $\mathrm{E}=$ dose of $\mathrm{LPG}$ resulting in a $50 \%$ response between the upper and the lower limit.

[e] $\mathrm{V} 2=2$-leaf stage.

[f] $\quad$ DAT $=$ days after treatment

[g] V5 = 5-leaf stage.

[h] DOUBLE = 2-leaf plus 3- or 4-leaf stage.

[i] $\mathrm{DAFT}=$ days after first treatment.

[j] DBST $=$ days before second treatment.

[k] DAST = days after second treatment.

dose, surviving weeds at 7 DAT were at a growth stage ranging from 5- to 11-leaf. The 11-leaf weeds comprised mainly Chenopodium album $\mathrm{L}$.

When maize was flamed with the highest LPG dose, the growth stage of weeds observed at 1 DBST at DOUBLE was $99 \%$ at the cotyledonary (newly emerged weeds) and $1 \%$ at mixed up to 5-leaf (surviving weeds after first flaming). When maize was flamed with an LPG dose of $52 \mathrm{~kg} \mathrm{ha}^{-1}$, weed growth stage was $92 \%$ at the cotyledonary (newly emerged weeds) and $8 \%$ at mixed up to 5-leaf (surviving weeds after first flaming).

\section{Weed Dry Biomass at Harvest}

In order to take the total sequence of weed emergence during the crop cycle into account, weed dry biomass at harvest was studied. Results showed that weed growth stage (corresponding to maize growth stage at the time of flaming) and repeated flame weeding during the growing season influenced weed responses to cross-flaming (fig. 4, table 6). Weed dry biomass at harvest of the nonflamed weedy control was on average $1870 \mathrm{~g} \mathrm{~m}^{-2}$ (upper limit of the curve), however, this was reduced by increasing LPG dose or time of application. Weed dry biomass at harvest was $532 \mathrm{~g} \mathrm{~m}^{-2}$ and $72 \mathrm{~g} \mathrm{~m}^{-2}$ (lower limit of the curve) when weeds were flamed at V5 and V2, respectively, with the highest LPG dose (e.g., $130 \mathrm{~kg} \mathrm{ha}^{-1}$ ) (table 6). A repeated flame weeding (16-day interval) (DOUBLE stage) with the highest LPG dose, applied when weeds were $99 \%$ at the cotyledonary stage showed a weed dry biomass at harvest of $41 \mathrm{~g} \mathrm{~m}^{-2}$ (lower limit of the curve) (table 6). This suggests that when weeds were flamed once at the cotyledonary stage (V2 stage of maize) weed dry biomass at harvest was smaller compared with maize flamed at V5, and larger compared with flame weeding repeated twice (DOUBLE stage of maize).

Table 6 shows the estimated LPG doses at ED-levels needed to obtain $70 \%, 80 \%$, and $90 \%$ weed control at harvest. With a minimum weed biomass of $532 \mathrm{~g} \mathrm{~m}^{-2}$ (table 6) observed at V5 stage, it was not possible to calculate the LPG dose needed for an $80 \%$ or $90 \%$ weed control at harvest. At V5 a weed control of $70 \%$ was obtained with an LPG dose larger than the LPG doses needed to obtain the same level of weed control when maize was flamed at V2 and DOUBLE, respectively (table 7). In order to maintain $70 \%$, $80 \%$, and $90 \%$ weed control, when cross-flaming was repeated twice (DOUBLE stage), the LPG dose needed for each application was smaller than when applied only once at V2 (table 7).

\section{Yields}

The yield of nonflamed weedy control was $2.3 \mathrm{Mg} \mathrm{ha}^{-1}$ (lower limit of the curve) (fig. 5, table 8), 8-fold smaller than the yield of the nonflamed weed-free control (table 3), thus highlighting that weed control is key in obtaining economically sustainable yields. In real-field weedy conditions, when the highest LPG dose (e.g., $130 \mathrm{~kg} \mathrm{ha}^{-1}$ ) was applied at V2 and V5, yields were 16.0 and $8.7 \mathrm{Mg} \mathrm{ha}^{-1}$, respectively (lower limit of the curve) (fig. 5 , table 8).

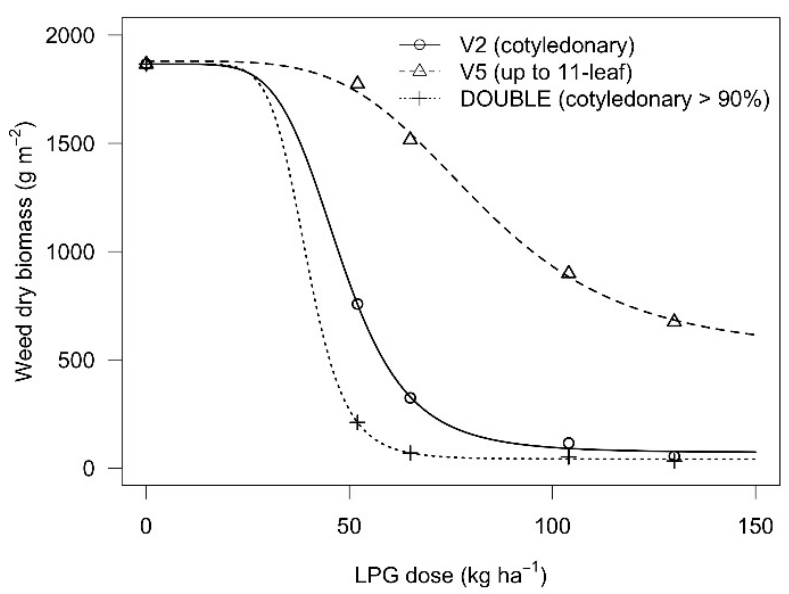

Figure 4. Influence of cross-flaming on weed dry biomass $\left(\mathrm{g} \mathrm{m}^{-2}\right)$ at harvest as affected by LPG dose and weed growth stage (corresponding to maize growth stage) at the time of application (V2: 2-leaf; V5: 5-leaf; DOUBLE: 2-leaf plus 3- or 4-leaf) under real-field weedy conditions. DOUBLE was flamed twice at an interval of 16 days. The regression lines are plotted using equation 1 , and the parameters are presented in table 6. 
Table 6. Regression parameters for weed dry biomass $\left(\mathrm{Mg} \mathrm{ha}^{-1}\right)$ at harvest as affected by LPG dose, and LPG doses (kg ha $\left.{ }^{-1}\right)$ needed to obtain $70 \%, 80 \%$ and $90 \%$ weed control at three growth stages of maize under real-field weedy conditions.

\begin{tabular}{|c|c|c|c|c|c|c|c|c|}
\hline \multicolumn{9}{|c|}{ Weed Biomass $\left(\mathrm{g} \mathrm{m}^{-2}\right)$} \\
\hline \multirow{2}{*}{\multicolumn{2}{|c|}{ Growth Stage }} & \multirow{2}{*}{\multicolumn{4}{|c|}{ Regression Parameters $( \pm \mathrm{SE})$}} & \multicolumn{3}{|c|}{ LPG Dose $( \pm \mathrm{SE})$} \\
\hline & & & & & & $70 \%$ & $80 \%$ & $90 \%$ \\
\hline Maize & Weeds & $\mathrm{B}^{[\mathrm{a}]}$ & $\mathrm{C}^{[\mathrm{b}]}$ & $\mathrm{D}^{[\mathrm{c}]}$ & $\mathrm{E}^{[\mathrm{d}]}$ & Weed Control & Weed Control & Weed Control \\
\hline $\mathrm{V} 2^{[\mathrm{e}]}$ & $\cot ^{[\mathrm{f}]}$ & $5.9(0.20)$ & $71.5(6.08)$ & $1866.0(7.25)$ & $47.9(0.22)$ & $56.4(0.23)$ & $62.9(0.43)$ & $75.7(0.96)$ \\
\hline $\mathrm{V} 5^{[\mathrm{g}]}$ & up to 11-leaf & $4.6(0.14)$ & $531.8(22.86)$ & $1879.5(6.82)$ & $82.9(1.03)$ & $186.0(6.44)$ & - & - \\
\hline DOUBLE $^{[\mathrm{h}]}$ & $\cot ^{[\mathrm{f}]}>90 \%$ & $8.4(1.44)$ & $41.2(5.34)$ & $1865.9(7.25)$ & $39.6(1.83)$ & $44.2(1.21)$ & $47.4(0.77)$ & $53.0(0.43)$ \\
\hline
\end{tabular}

[b] $\mathrm{C}=$ lower limit. The value of $\mathrm{C}$ is the weed biomass when the highest LPG dose was applied.

[c] $\mathrm{D}=$ upper limit. The value of $\mathrm{D}$ is the weed biomass of the nonflamed weedy control.

[d] $\mathrm{E}=$ dose of LPG resulting in a 50\% response between the upper and the lower limit.

[e] $\mathrm{V} 2=2$-leaf stage.

[f] $\cot =$ cotyledonary stage.

[g] $\mathrm{V} 5=5$-leaf stage.

[h] DOUBLE $=$ 2-leaf plus 3 or 4-leaf stage.

Table 7. Comparison of potencies among relative response levels (producing $70 \%, 80 \%$, and $90 \%$ weed control) from curves $\mathrm{V} 2$ (2-leaf) (cotyledonary), V5 (5-leaf) (up to 11-leaf), and DOUBLE (2-leaf plus 3- or 4-leaf) (cotyledonary $>90 \%$ ) presented in figure 4.

\begin{tabular}{lcc}
\hline & $\begin{array}{c}\text { Relative Potency } \\
( \pm \mathrm{SE})\end{array}$ & p-value $^{[\mathrm{a}]}$ \\
\hline Response Level & $1.28(0.04)$ & 0.00 \\
V2/DOUBLE:72/72 & $3.30(0.11)$ & 0.00 \\
V5/V2:98/72 & $4.21(0.19)$ & 0.00 \\
V5/DOUBLE:98/72 & $1.33(0.02)$ & 0.00 \\
80\% weed control & $1.43(0.02)$ & 0.00 \\
$\quad$ V2/DOUBLE:83/82 & & \\
90\% weed control & & \\
$\quad$ V2/DOUBLE:94/92 &
\end{tabular}

The predicted yields from weedy and weed-free curves were compared for V2 and V5 growth stages (table 9). Results showed that when maize was flamed in weedy conditions the levels of non-controlled weeds observed at harvest led to smaller yields than that observed in weed-free conditions.

The yield of maize flamed twice at an interval of 16 days (DOUBLE stage) in weedy conditions increased by increasing the LPG dose until reaching an estimated peak, after which the yield decreased by increasing LPG dose (fig. 6). The increase was probably due to the ability of the flame

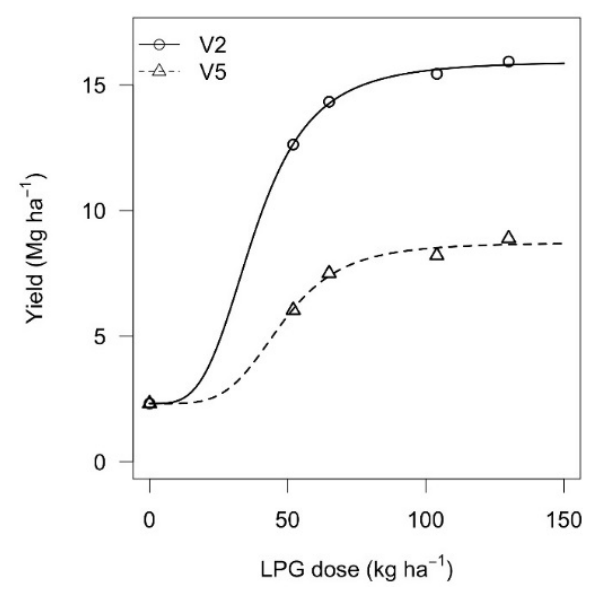

Figure 5. Influence of cross-flaming on maize yield $\left(\mathrm{Mg} \mathrm{ha}^{-1}\right)$ as affected by LPG dose, weeds, and V2 and V5 maize growth stage (V2: 2-leaf; V5: 5-leaf) under real-field weedy conditions. The regression lines are plotted using equation 1 , and the parameters are presented in table 8 .
Table 8. Regression parameters for maize yield as affected by LPG dose, weeds, and V2 and V5 maize growth stage under real-field weedy conditions.

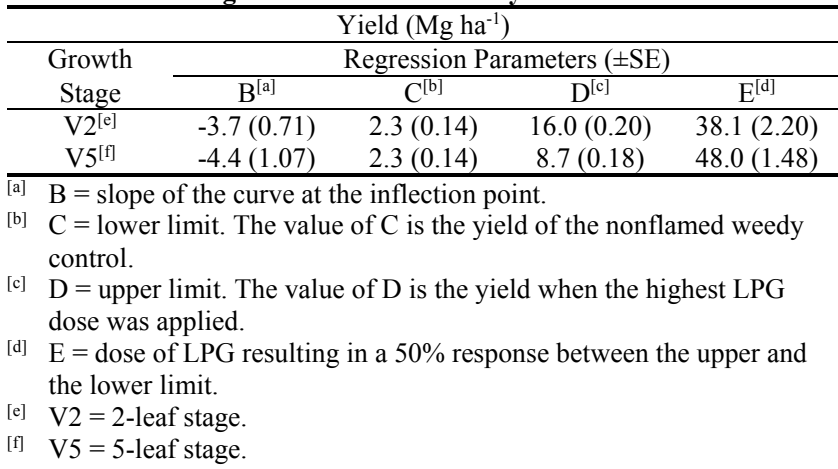

weeding to control weeds at a favorable period in order to avoid weed/crop competition. The maximum yield corresponding to the estimated peak was $17.4( \pm 1.09) \mathrm{Mg} \mathrm{ha}^{-1}$ with an LPG dose of $38( \pm 1.03) \mathrm{kg} \mathrm{ha}^{-1}$ applied twice (16-day interval), which was similar to the yield of the nonflamed weed-free control (table 3). Predicted yields from weed-free curve (fig. 2) and weedy curve (fig. 6) were similar (table 10). This thus suggests that yields estimated in weedy conditions after the peak were not influenced by weeds, but was due to maize sensitivity when flamed with high LPG doses. Before the estimated peak the maize yield was influenced by the presence of weeds.

\section{DisCUSSION}

In weed-free conditions, with all LPG doses maize flamed at V5 stage showed a higher yield compared with maize flamed at V2 and DOUBLE stages. Ulloa et al. (2011a) also

Table 9. Predicted yields from weedy and weed-free curves (figs. 5 and 2, respectively) at the lower LPG dose of the $95 \%$ CI needed to obtain $70 \%, 80 \%$, and $90 \%$ weed control at harvest estimated from weed dry biomass curves V2 (2-leaf) and V5 (5-leaf) (fig. 4, table 6).

\begin{tabular}{ccccc}
\hline \multirow{2}{*}{$\begin{array}{c}\text { Growth } \\
\text { Stage }\end{array}$} & $\begin{array}{c}\text { L } \begin{array}{c}\text { Lower } \\
\left(\mathrm{kg} \mathrm{ha}^{-1}\right)\end{array} \\
\text { V2 }\end{array}$ & $\begin{array}{c}\text { Weed } \\
(\%)\end{array}$ & \multicolumn{2}{c}{$\begin{array}{c}\text { Predicted Yield }( \pm \text { SE }) \\
\left(\mathrm{Mg} \mathrm{ha}^{-1}\right)\end{array}$} \\
\cline { 4 - 5 } V2 & 56.0 & 70 & $13.3(0.11)$ & $17.7(0.02)$ \\
V2 & 62.1 & 80 & $14.0(0.13)$ & $17.6(0.03)$ \\
V5 & 73.8 & 90 & $14.8(0.14)$ & $17.2(0.04)$ \\
\hline
\end{tabular}




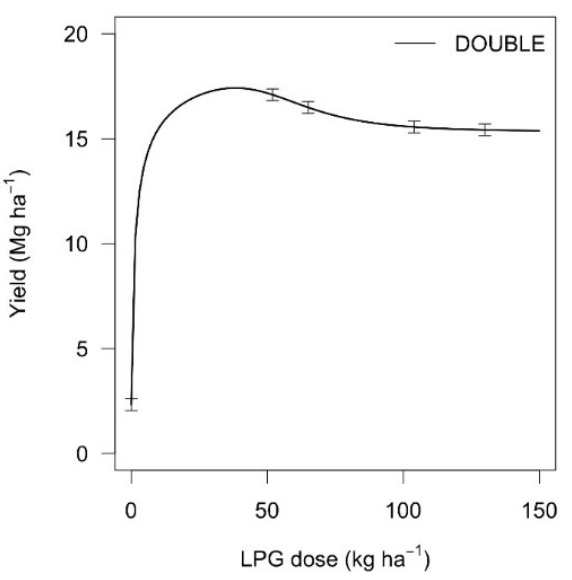

Figure 6. Influence of cross-flaming on maize yield $\left(\mathrm{Mg} \mathrm{ha}^{-1}\right)$ as affected by LPG dose, weeds, and DOUBLE maize growth stage (DOUBLE: 2leaf plus 3- or 4-leaf) under real-field weedy conditions. DOUBLE was flamed twice at an interval of $\mathbf{1 6}$ days. The regression line is plotted using equation 2 , and the parameters are presented in table 10 .

found that maize flamed at V5 with the highest propane dose had a higher yield than maize flamed at V2. The key to flame weeding is to position the burners (heat source) so that the growing point of the crop is protected during flaming (Datta and Knezevic, 2013). By applying cross-flaming with open flame rod burners instead of broadcast flaming with torches (Ulloa et al., 2011a), V2 can tolerate higher doses for the same yield losses.

Datta et al. (2013) tested single and repeated flame weeding on maize in weed-free conditions with a propane dose of $50 \mathrm{~kg} \mathrm{ha} \mathrm{k}^{-1}$. The results showed that yields of maize flamed once (at V2) and twice (at V2 and V4) were similar. In our test, estimated yield in plots flamed at V2 with an LPG dose of $50 \mathrm{~kg} \mathrm{ha}^{-1}$ was larger than the yield of maize flamed twice at DOUBLE. Differences between Datta et al.'s (2013) and ours findings were probably linked to the fact that in their study maize was not in direct contact with heat, as it was in our study, and maize flamed twice was more tolerant to their flaming technique than cross-flaming.

In our real-field test, where crop and weeds were simultaneously in the field, a mixed weed composition consisting of $64 \%$ of Chenopodium album L., 20\% of Datura stramonium L., and $16 \%$ of other species at the cotyledonary stage was controlled by flame weeding at a level of 99-100\% observed at 7 DAT when maize was flamed with the highest LPG dose (e.g., $130 \mathrm{~kg} \mathrm{ha}^{-1}$ ) at V2 (table 5). The same weed composition was at a mixed growth stage when maize was flamed at V5, as a consequence of a scalar weed emergence, with a maximum 11-leaf weed growth stage comprised mainly Chenopodium album L. In this case the weed control level observed at 7 DAT was $81 \%$ to $84 \%$ (table 5). Our results are similar to those of others (Ascard 1994, 1995; Cisneros and Zandstra 2008; Sivesind et al., 2009; Ulloa et al., 2010b,c; Knezevic et al., 2014), who reported that small plants are more sensitive to heat than large ones. Repeated flame weeding (at V2 and 16 days after) extended the time of competitive advantage of crop against weeds by 14 days for all the range of LPG doses tested (fig. 3).

The yield decreases observed when maize was flamed at V2 and V5 in weedy conditions were economically unacceptable. Maize flamed at the DOUBLE stage showed a similar yield to the nonflamed weed-free control when maize was flamed in weedy conditions with a range of LPG doses from 36 to $42 \mathrm{~kg} \mathrm{ha}^{-1}$. The dose of $60 \mathrm{~kg} \mathrm{ha}^{-1}$, indicated by Datta and Knezevic (2013) as the most effective dose to control $80 \%$ to $90 \%$ of several annual broadleaf weeds and many grasses, and that led to a yield loss of 3\% in maize flamed in weed-free conditions at V5, and resulting below the arbitrarily assigned acceptable yield reduction of about 5\% (Datta and Knezevic, 2013), should also be observed in real-field weedy conditions.

By flaming the weeds twice, firstly at V2 and secondly after 16 days (DOUBLE growth stage), with LPG doses ranging from 36 to $42 \mathrm{~kg} \mathrm{ha}^{-1}$ it might be possible to stay inside the critical period for weed control. This critical period is the interval between two separately measured cropweed competition components: (1) the critical timing of weed removal or the maximum amount of time that earlyseason weed competition can be tolerated by the crop before the crop suffers irrevocable yield reduction, and (2) the critical weed-free period or the minimum weed-free period required from the time of planting to prevent unacceptable yield reductions (Knezevic et al., 2002).

\section{CONCLUSIONS}

The overall response of maize yield to single and repeated cross-flaming was influenced by LPG dose, number of applications, maize growth stage, and the presence of weeds. Maize flamed at V2 and V5 in weedy conditions showed a minimum yield decrease of $10 \%$ to $14 \%$ and $50 \%$, respectively, compared with the yield observed in nonflamed

\begin{tabular}{|c|c|c|c|c|}
\hline \multirow{2}{*}{$\begin{array}{c}\text { Yield }\left(\mathrm{Mg} \mathrm{ha}^{-1}\right) \\
\text { Regression Parameters }( \pm \mathrm{SE})\end{array}$} & \multirow{2}{*}{$\begin{array}{l}\text { Lower LPG Dose } \\
\left(\mathrm{kg} \mathrm{ha}^{-1}\right)\end{array}$} & \multirow{2}{*}{$\begin{array}{c}\text { Weed Control } \\
(\%) \\
\end{array}$} & \multicolumn{2}{|c|}{ Predicted Yield $\left( \pm\right.$ SE) $\left(\mathrm{Mg} \mathrm{ha}^{-1}\right)$} \\
\hline & & & WEEDY & WEED-FREE \\
\hline $\mathrm{B}^{[\mathrm{a}]} \quad 4.7(4.87)$ & 41.8 & 70 & $17.4(0.76)$ & $17.6(0.04)$ \\
\hline $15.3(0.37)$ & 45.9 & 80 & $17.3(0.43)$ & $17.4(0.05)$ \\
\hline $2.3(0.13)$ & 52.2 & 90 & $17.1(0.13)$ & $17.1(0.08)$ \\
\hline $59.3(19.06)$ & & & & \\
\hline $18.1(2.56)$ & & & & \\
\hline
\end{tabular}


weed-free control, which may not be acceptable for producers. In maize flamed twice (DOUBLE stage) in real-field weedy conditions we found a reduction in weed competitive ability against the crop which led to similar yields to those observed in nonflamed weed-free control plots when an LPG dose ranging from 36 to $42 \mathrm{~kg} \mathrm{ha}^{-1}$ was applied. This suggests that two cross-flaming treatments applied separately (firstly at V2 and secondly after 16 days) with an LPG dose ranging from 36 to $42 \mathrm{~kg} \mathrm{ha}^{-1}$ (which does not lead to yield loss due to non-tolerance of maize) can provide an acceptable level of weed control in maize, enough to ensure economically acceptable yields.

The selected doses of 36 to $42 \mathrm{~kg} \mathrm{ha}^{-1}$ are expressed as effective biological doses, which is the amount of LPG per unit surface distributed in the $0.25 \mathrm{~m}$ of intra-row. The LPG consumptions (LPG amount per unit surface) of the machine corresponding to these biological doses are 12 to $14 \mathrm{~kg} \mathrm{ha}^{-1}$ when burners are switched-on across the entire surface of the field. Lower consumptions can be achieved by switching the burners on and off based on different weed spatial arrangements as identified by a weed detection system in the field.

The results of this study suggest that cross-flaming could be used both in organic and conventional maize production, by selecting the right maize growth stage, LPG doses and time of application based on weed growth stage. Depending on the needs of the producers, the technique could be used alone or be integrated with other weed control strategies. Flame weeding is significantly less expensive than hand weeding and organic herbicides (Nemming, 1994), and there is no chance for weeds to develop resistance to the instant heat produced by machine burners.

\section{ACKNOWLEDGEMENTS}

The RHEA Project was funded by the European Union's Seventh Framework Programme [FP7/2007-2013] under Grant Agreement No. 245986 in the Theme NMP-2009-3.41 (Automation and robotics for sustainable crop and forestry management). The authors would like to thank Roberta Del Sarto and Calogero Plaia (Department of Agriculture Food and Environment, University of Pisa) and all the staff of the CiRAA "E. Avanzi" (University of Pisa) for their contribution to the development of the automatic machine and the planning and management of field experiments.

\section{REFERENCES}

Ascard, J. (1994). Dose-response models for flame weeding in relation to plant size and density. Weed Res., 34(5), 377-385. http://dx.doi.org/10.1111/j.1365-3180.1994.tb02007.x

Ascard, J. (1995). Effects of flame weeding on weed species at different developmental stages. Weed Res., 35(5), 397-411. http://dx.doi.org/10.1111/j.1365-3180.1995.tb01636.x

Bates, D., Maechler, M., Bolker, B., \& Walker, S. (2014). lme4: Linear mixed-effects models using Eigen and S4. Retrieved from http://CRAN.R-project.org/package=lme4

Cedergreen, N., Ritz, C., \& Streibig, J. C. (2005). Improved empirical models describing hormesis. Environ. Toxicol. Chem., 24(12), 3166-3172. http://dx.doi.org/10.1897/05-014R.1

Cisneros, J. J., \& Zandstra, B. H. (2008). Flame weeding effects on several weed species. Weed Technol., 22(2), 290-295. http://dx.doi.org/10.1614/WT-07-113.1
Consorzio LaAMMA,. (2013). Report metereologici. Retrieved from http://www.lamma.rete.toscana.it/clima-eenergia/climatologia/report-mensili-toscana. [In Italian]

Datta, A., \& Knezevic, S. Z. (2013). Flaming as an alternative weed control method for conventional and organic agronomic crop production systems: A review. In D. Sparks (Ed.), Advances in Agronomy (Vol. 118, pp. 399-428). Academic Press. http://dx.doi.org/10.1016/B978-0-12-405942-9.00006-2

Datta, A., Stepanovic, S., Nedeljkovic, D., Bruening, C., Gogos, G., \& Knezevic, S. Z. (2013). Impact of single and repeated flaming on yield components and yield of maize. Organic Agric., 3(3), 141-147. http://dx.doi.org/10.1007/s13165-013-0053-z

Fontanelli, M., Raffaelli, M., Martelloni, L., Frasconi, C., \& Peruzzi, A. (2013). The influence of non-living mulch, mechanical and thermal treatments on weed population and yield of rainfed fresh-market tomato (Solanum lycopersicum L.). Spain. J. Agric. Res., 11(3), 593-602. http://dx.doi.org/10.5424/sjar/2013113-3394

Frasconi, C., Martelloni, L., Fontanelli, M., Raffaelli, M., Emmi, L., Pirchio, M., \& Peruzzi A. (2014). Design and full realization of physical weed control (PWC) automated machine within the RHEA Project. Proc. 2nd Int. Conf. Robotics and Associated High-Technologies and Equipment for Agriculture and Forestry (pp. 3-11). PGM.

Hatcher, P. E., \& Melander, B. (2003). Combining physical, cultural and biological methods: Prospects for integrated non-chemical weed management strategies. Weed Res., 43(5), 303-322. http://dx.doi.org/10.1046/j.1365-3180.2003.00352.x

Knezevic, S. Z., Evans, S. P., Blankenship, E. E., Van Acker, R. C., \& Lindquist, J. L. (2002). Critical period for weed control: The concept and data analysis. Weed Sci., 50(6), 773-786. http://dx.doi.org/10.1614/00431745(2002)050[0773:CPFWCT]2.0.CO;2

Knezevic, S. Z., Streibig, J. C., \& Ritz, C. (2007). Utilizing R software package for dose-response studies: The concept and data analysis. Weed Technol., 21(3), 840-848. http://dx.doi.org/10.1614/WT-06-161.1

Knezevic, S. Z., Stepanovic, S., Datta, A., Nedeljkovic, D., \& Tursun, N. (2013). Soybean yield and yield components as influenced by the single and repeated flaming. Crop Prot., 50, 15. http://dx.doi.org/10.1016/j.cropro.2013.03.014

Knezevic, S. Z., Stepanovic, S., \& Datta, A. (2014). Growth stage affects response of selected weed species to flaming. Weed Technol., 28(1), 233-242. http://dx.doi.org/10.1614/WT-D-1300054.1

Kuznetsova, A., Brockhoff, P. B., \& Christensen, R. H. B. (2014). lmerTest: Tests for random and fixed effects for linear mixed effect models. Retrieved from http://CRAN.Rproject.org/package $=$ lmerTest

Mojžiš, M. (2002). Energetic requirements of flame weed control. Res. Agric. Eng., 48, 94-97.

Nemming, A. (1994). Costs of flame cultivation. Acta Hortic., 372, 205-212. http://dx.doi.org/10.17660/ActaHortic.1994.372.24

Nielsen, R. L. (2010). Determining corn leaf stages. Corny News Network. Retrieved from

http://www.agry.purdue.edu/ext/corn/news/timeless/vstagemeth ods.html

Peruzzi, A., Ginanni, M., Fontanelli, M., Raffaelli, M., \& Barberi, P. (2007). Innovative strategies for on-farm weed management in organic carrot. Renewable Agric. Food Syst, 22(4), 246-259. http://dx.doi.org/10.1017/S1742170507001810

R Core Team. (2013). R: A language and environment for statistical computing. R Foundation for statistical computing. 
Raffaelli, M., Martelloni, L., Frasconi, C., Fontanelli, M., \& Peruzzi, A. (2013). Development of machines for flaming weed control on hard surfaces. Trans. ASABE, 29(5). http://dx.doi.org/10.13031/aea.29.10143

Rask, A. M., Kristoffersen, P., \& Andreasen, C. (2012). Controlling grass weeds on hard surfaces: Effect of time intervals between flame treatments. Weed Technol., 26(1), 83-88. http://dx.doi.org/10.1614/WT-D-11-00031.1

RHEA Project. (2014). Robot fleets for highly effective agriculture and forestry management. Retrieved from http://www.rheaproject.eu/index.php

Ritz, C. \&. (2005). Bioassay analysis using R. J. Stat. Softw., 12(5), 1-22. http://dx.doi.org/10.18637/jss.v012.i05

Ritz, C., \& Streibig, J. C. (2012). Dose response curves and other nonlinear curves in Weed Science and Ecotoxicology with the add-on package drc in R. Retrieved from http://bioassay.dk

Ritz, C., Cedergreen, N., Jensen, J. E., \& Streibig, J. C. (2006). Relative potency in nonsimilar dose-response curves. Weed Sci., 54(3), 407-412. http://dx.doi.org/10.1614/WS-05-185R.1

Seefeldt, S. S., Jensen, J. E., \& Fuerst, E. P. (1995). Log-logistic analysis of herbicide dose-response relationships. Weed Technol., 9(2), 218-227.

Sivesind, E. C., Leblanc, M. L., Cloutier, D. C., Seguin, P., \& Stewart, K. A. (2009). Weed response to flame weeding at different developmental stages. Weed Technol., 23(3), 438-443. http://dx.doi.org/10.1614/WT-08-155.1

Sivesind, E. C., Leblanc, M. L., Cloutier, D. C., Seguin, P., \& Stewart, K. A. (2012). Impact of selective flame weeding on onion yield, pungency, flavonoid concentration, and weeds. Crop Prot., 39, 45-51. http://dx.doi.org/10.1016/j.cropro.2012.03.009
Ulloa, S. M., Datta, A., Malidza, G., Leskovsek, R., \& Knezevic, S. Z. (2010a). Timing and propane dose of broadcast flaming to control weed population influenced yield of sweet maize (Zea mays L. var. rugosa). Field Crops Res., 118(3), 282-288. http://dx.doi.org/10.1016/j.fcr.2010.06.007

Ulloa, S. M., Datta, A., \& Knezevic, S. Z. (2010b). Growth stageinfluenced differential response of foxtail and pigweed species to broadcast flaming. Weed Technol., 24(3), 319-325. http://dx.doi.org/10.1614/WT-D-10-00005.1

Ulloa, S. M., Datta, A., \& Knezevic, S. Z. (2010c). Tolerance of selected weed species to broadcast flaming at different growth stages. Crop Prot., 29(12), 1381-1388. http://dx.doi.org/10.1016/j.cropro.2010.07.017

Ulloa, S. M., Datta, A., Bruening, C., Neilson, B., Miller, J., Gogos, G., \& Knezevic, S. (2011a). Maize response to broadcast flaming at different growth stages: Effects on growth, yield and yield components. Eur. J. Agron., 34(1), 10-19. http://dx.doi.org/10.1016/j.eja.2010.09.002

Ulloa, S. M., Datta, A., \& Knezevic, S. Z. (2011b). Growth stage influenced sorghum response to broadcast flaming: Effects on yield and its components. Agron. J., 103(1). http://dx.doi.org/10.2134/agronj2010.0247

Wheeler, M. W., Park, R. M., \& Bailer, A. J. (2006). Comparing median lethal concentration values using confidence interval overlap or ratio tests. Environ. Toxicol. Chem., 25(5), 14411444. http://dx.doi.org/10.1897/05-320R.1 